\title{
Influence of Multiple Bioprocess Parameters on Production of Lipase from Pseudomonas sp. BWS-5
}

\author{
Balwinder Singh Sooch * and Baljinder Singh Kauldhar \\ Enzyme Biotechnology Laboratory, Department of Biotechnology, Punjabi University - India
}

\begin{abstract}
The aim of the present work was to study the influence of multiple bioprocess parameters for the maximum production of lipase from Pseudomonas sp. BWS-5. The culture reached the stationary phase of growth after $36 \mathrm{~h}$ of incubation when the maximum lipase production was obtained at flask level. The different media components such as carbon sources, nitrogen sources, trace elements and process parameters such as the $p H$ of the medium, temperature and time of incubation, agitation/stationary conditions, etc. were optimized at flask level and at bioreactor level. The maximum enzyme production of $298 \mathrm{IU} / \mathrm{mL}$ was obtained with the use of simple medium with pH 6.5 containing glucose $(1 \%, w / v)$, peptone $(3 \%, w / v)$ and $\mathrm{KCl}(0.05 \%, w / v)$ after $30 \mathrm{~h}$ of incubation at $37^{\circ} \mathrm{C}$ under agitation (200 rpm) conditions with $0.75 \mathrm{vvm}$ of air supply.
\end{abstract}

Key words: Lipase, Pseudomonas, Medium Optimization

\section{INTRODUCTION}

Lipases (triacylglycerol acylhydrolases EC 3.1.1.3) are ubiquitous enzymes of considerable physiological significance and industrial potential. The natural function of lipases is to hydrolyze the triglycerides into diglycerides, monoglycerides, fatty acids and glycerol. Thus, lipases can acylate alcohols, sugars, thiols and amines, synthesizing a variety of stereo-specific esters, sugar esters, thioesters and amides (Singh et al. 2003; Kashmiri et al. 2006). Lipases also show extreme versatility regarding fatty-acyl-chain-length specificity, regiospecificity and chiral selectivity (Beisson et al. 2000).

Numerous species of bacteria, yeast, fungi and moulds produce lipases with different enzymological properties and specificities but moulds are known to be more potent lipase producers (Choo et al. 1998). Microbial lipolytic enzymes are currently attracting an enormous attention because of their biotechnological potential (Pandey et al. 1999). Lipases constitute the most important group of biocatalysts for biotechnological applications and some important areas of lipase applications are detergents (Saad 1995), oleochemical, organic synthesis, leather processing (Iwai and Tsujisaka 1984), food technology (Reed 1975), waste water treatment, cosmetics and pharmaceuticals etc. (Elibol and Ozer 2000; Patel et al. 2005; Thirunavukarasu et al. 2008). Major improvements in the productivity of a fermentation process can be achieved by modifying the parameters such as the physicochemical and nutritional parameter, to which organism is exposed. The increasing potential of lipase applications prompts screening for new lipase producing microorganisms that can meet the conditions favourable for industrial applications. Therefore, the present study was

*Author for correspondence: soochb@yahoo.com 
undertaken to explore the lipase production ability of a newly isolated strain of Pseudomonas sp. BWS-5.

\section{MATERIALS AND METHODS}

\section{Bacterial Culture, Media and Culture Conditions}

The culture of Pseudomonas sp. BWS-5 was isolated from a soil of an automobile repair workshop of Patiala city, India. It was preserved on nutrient agar slants $(\mathrm{pH}=7.0)$ containing peptides digest of animal tissue $(5.0 \mathrm{~g} / \mathrm{L}), \mathrm{NaCl}$ $(5.0 \mathrm{~g} / \mathrm{L})$, beef extract $(1.5 \mathrm{~g} / \mathrm{L})$, yeast extract $(1.5$ $\mathrm{g} / \mathrm{L})$, agar powder $(15.0 \mathrm{~g} / \mathrm{L})$ by sub-culturing fortnightly. Inoculum at a concentration of $2 \%$ $(\mathrm{v} / \mathrm{v})$ in a nutrient broth medium with above composition except agar was used after incubating at $37^{\circ} \mathrm{C}$ for $12 \mathrm{~h}$. Fermentation medium $(50 \mathrm{~mL})$ containing olive oil $(1 \%, \mathrm{v} / \mathrm{v}), \mathrm{NaCl}(5.0 \mathrm{~g} / \mathrm{L})$, beef extract $(1.5 \mathrm{~g} / \mathrm{L})$, peptone $(3 \mathrm{~g} / \mathrm{L})$, yeast extract $(1.5 \mathrm{~g} / \mathrm{L})$ and having a $\mathrm{pH}=7.0$ was sterilized at $121^{\circ} \mathrm{C}$ for $20 \mathrm{~min}$ and was used for the production of lipase from Pseudomonas sp. BWS-5 under shaking conditions (100 rpm), unless otherwise specified. The effect of various carbon sources like fructose $(1 \%, \mathrm{w} / \mathrm{v})$, glucose $(1 \%, \mathrm{w} / \mathrm{v})$, sucrose $(1$ $\%, \mathrm{w} / \mathrm{v})$, starch $(1 \%, \mathrm{w} / \mathrm{v})$, olive oil $(1 \%, \mathrm{v} / \mathrm{v})$, mustard oil $(1 \%, \mathrm{v} / \mathrm{v})$, coconut oil $(1 \%, \mathrm{v} / \mathrm{v})$ and almond oil $(1 \%, \mathrm{v} / \mathrm{v})$ were investigated for production of lipase. The effect of various combinations of selected carbon sources and inducer (olive oil) were also studied. Various nitrogen sources such as yeast extract, beef extract, malt extract, peptone, urea and ammonium nitrate were supplemented in the medium at a concentration of 0.5 and $1 \%(\mathrm{w} / \mathrm{v})$ to study their effect on lipase production. The effect of various combinations of nitrogen sources was also studied. Different concentrations $(0.01,0.05$ and $0.1 \%, \mathrm{w} / \mathrm{v})$ of trace elements such as $\mathrm{FeSO}_{4}, \mathrm{CuSO}_{4}, \mathrm{NaCl}$, $\mathrm{MgSO}_{4}, \mathrm{SDS}$, Tween 80, $\mathrm{CaCl}_{2},\left(\mathrm{NH}_{4}\right)_{6} \mathrm{Mo}_{7} \mathrm{O}_{24}$, $\mathrm{MnCl}_{2}$ and $\mathrm{KCl}$ were supplemented independently and in combination to study their effect on lipase production.

\section{Process Parameter Studies}

The effect of various process parameters such as $\mathrm{pH}$ of media $(4.0-8.0)$, temperature $\left(25-45^{\circ} \mathrm{C}\right)$ and time of incubation $(0-72 \mathrm{~h})$, and agitation/stationary conditions were investigated for maximum production of lipase from Pseudomonas sp. BWS-5 at flask level.

\section{Bioreactor Studies}

Bioreactor studies were conducted in a lab scale $(1.5 \mathrm{~L})$ stirred tank reactor (Biolab, B. Braun, Germany), fitted with a Rushton type impeller with six blades and working volume of $1 \mathrm{~L}$ with aeration and agitation at $1.0 \mathrm{vvm}$ and $150 \mathrm{rpm}$, respectively. Various parameters such as agitation (50 - $300 \mathrm{rpm})$, aeration rate $(0.25-2.25 \mathrm{vvm})$ and incubation time $(0-54 \mathrm{~h})$ were optimized for the production of lipase in a batch system. To control the foam formation, sterilized silicone oil $(0.002 \%$, w/v) was added two times at the beginning and 30 $\mathrm{h}$ of fermentation.

\section{Enzyme Assay}

The biomass was separated by centrifugation at $3,000 \mathrm{~g}$ for $10 \mathrm{~min}$ at $4^{\circ} \mathrm{C}$. The supernatant thus obtained was analyzed for enzyme activity at $37^{\circ} \mathrm{C}$ by the method of Jensen et al. (1983). One unit (IU) of enzyme was defined as that releases one $\mu \mathrm{M}$ of fatty acids per minute from triacylglycerols under assay conditions.

\section{RESULTS AND DISCUSSION}

\section{Lipase Production vs Growth Pattern of Pseudomonas sp. BWS-5}

Figure 1 shows the growth pattern of the bacterial culture. The maximum lipase production of 38.4 $\mathrm{IU} / \mathrm{mL}$ was observed at $36 \mathrm{~h}$ of fermentation and thereafter, enzyme activity was approximately constant up to $42 \mathrm{~h}$, thereafter it decreased. The enzyme production progressively increased during the log phase of growth and reached its maximum level when the culture reached the stationary phase of growth after $36 \mathrm{~h}$. Maximum lipase activity from Pseudomonas sp. MS1057 has also been recorded in the stationary phase of growth (Kiran and Shanmughapriya 2008). The results are also in agreement with the findings reported by Gupta et al. (2004).

\section{Medium Optimization Studies at Shake Flask Level \\ Effect of carbon source \\ The effect of various tested carbon sources on enzyme production is shown in Figure 2. The maximum enzyme activity of $76.0 \mathrm{IU} / \mathrm{mL}$ was}


achieved after $36 \mathrm{~h}$ of incubation by use of glucose as sole carbon source in the medium.

The effect of inducer on lipase production was also studied by using different concentrations $(0.1$ - $1 \%, \mathrm{v} / \mathrm{v})$ of olive oil in the medium. It was observed that the enzyme was not inducible in nature because there was no increase in lipase production when different concentrations of olive oil along with glucose $(1 \%, \mathrm{w} / \mathrm{v})$ were used in the medium (Table 1). Hence, it could be concluded that lipase produced by Pseudomonas sp. BWS-5 was constitutive in nature. Most of bacterial lipases reported so far are constitutive and nonspecific in their substrate specificity (Gupta et al. 2004).

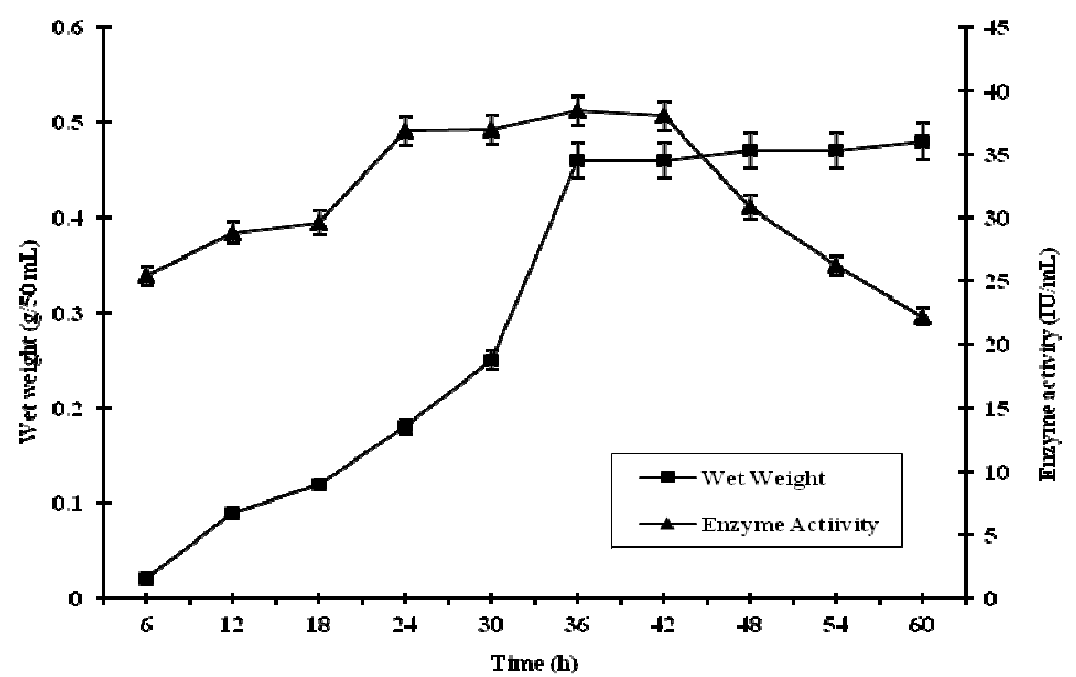

Figure 1 - Lipase production vs growth pattern of Pseudomonas sp. BWS-5.

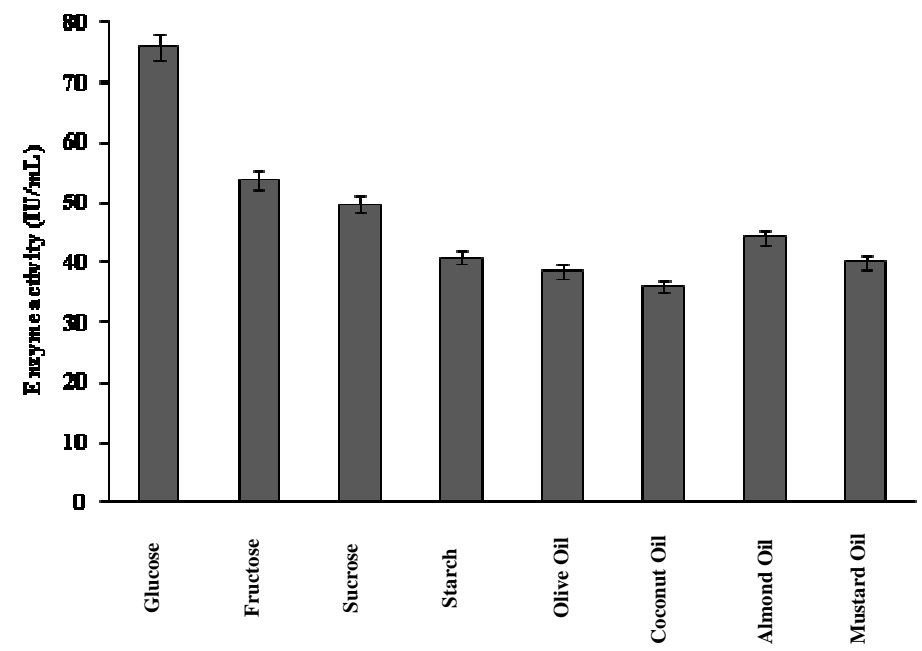

Figure 2 - Lipase production by Pseudomonas sp. BWS-5 with carbon source as a function.

Table 1 - Effect of inducer on lipase production.

\begin{tabular}{lc}
\hline Combination & Enzyme activity (IU/mL) \\
\hline Glucose $(1 \%, w / v)+$ No Inducer & 76.0 \\
Glucose $(1 \%, w / v)+$ Inducer $(0.1 \%, v / v)$ & 72.0 \\
Glucose $(1 \%, w / v)+$ Inducer $(0.5 \%, \mathrm{v} / \mathrm{v})$ & 70.1 \\
Glucose $(1 \%, \mathrm{w} / \mathrm{v})+$ Inducer $(1 \%, \mathrm{v} / \mathrm{v})$ & 67.3 \\
\hline
\end{tabular}


Different concentrations $(0.5-2.5 \%$, w/v $)$ of glucose were supplemented in the medium to study their effect on lipase production. A progressive increase in enzyme production was observed with the increase in glucose concentration up to $1 \%(\mathrm{w} / \mathrm{v})$ and thereafter, a decline in enzyme activity was observed
(Fig. 3). The maximum lipase production of 76 $\mathrm{IU} / \mathrm{mL}$ was recorded. Kiran and Shanmughapriya (2008) reported the maximum lipase production with $2.5 \%(\mathrm{w} / \mathrm{v})$ glucose by Pseudomonas sp. (MSI057).

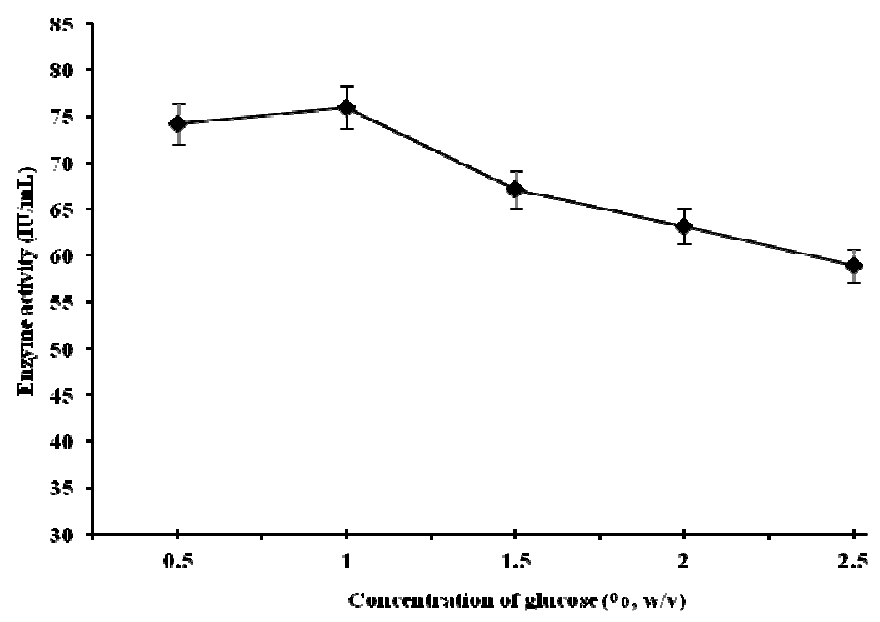

Figure 3 - Lipase production by Pseudomonas sp. BWS-5 as a function of different concentrations of glucose.

\section{Effect of nitrogen source}

Various nitrogen sources (Yeast extract, Beef extract, Malt extract, Peptone, Urea and Ammonium nitrate) were supplemented individually (Fig. 4) and in combination (Table 2) at the concentration of 0.5 and $1 \%(\mathrm{w} / \mathrm{v})$ in the medium to test their influence on lipase production. The maximum lipase production of $75.4 \mathrm{IU} / \mathrm{mL}$ was supported by peptone at $1 \%$ $(\mathrm{w} / \mathrm{v})$. The organic nitrogen sources were better than inorganic nitrogen sources. This finding was in agreement with several reports on lipase production from Pseudomonas sp. as reviewed by Gupta et al. (2004). Ammonium salts usually causes acidic condition, because free acid is librated in the medium after the utilization of ammonium ions and high acidic condition may inhibit the growth of the culture and synthesis of lipase by it. Table 2 showed that combinations of different nitrogen sources tested had no significant effect on lipase production.

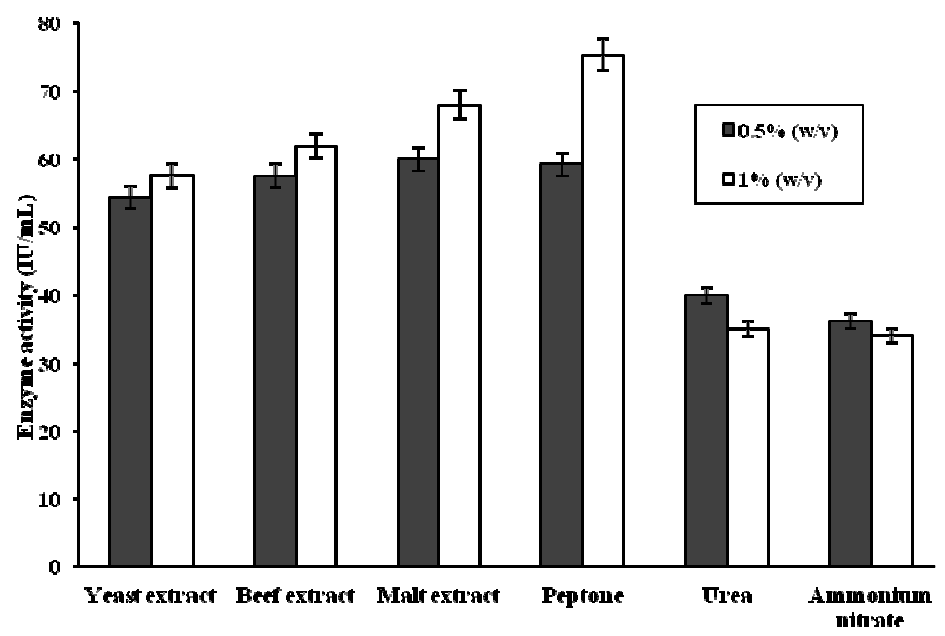

Figure 4 - Lipase production by Pseudomonas sp. BWS-5 with nitrogen source as a function. 
Table 2 - Different combinations of nitrogen sources.

\begin{tabular}{lc}
\hline Combination of Nitrogen Sources & Enzyme activity (IU/ml) \\
\hline Control $($ Peptone, $1 \%, \mathrm{w} / \mathrm{v})$ & 75.4 \\
Peptone $(1 \%, \mathrm{w} / \mathrm{v})+$ Yeast extract $(1 \%, \mathrm{w} / \mathrm{v})$ & 76.4 \\
Peptone $(0.5 \%, \mathrm{w} / \mathrm{v})+$ Yeast extract $(0.5 \%, \mathrm{w} / \mathrm{v})$ & 70.3 \\
Peptone $(1 \%, \mathrm{w} / \mathrm{v})+$ Malt extract $(1 \%, \mathrm{w} / \mathrm{v})$ & 65.3 \\
Peptone $(0.5 \%, \mathrm{w} / \mathrm{v})+$ Malt extract $(0.5 \%, \mathrm{w} / \mathrm{v})$ & 46.9 \\
Peptone $(1 \%, \mathrm{w} / \mathrm{v})+$ Beef extract $(1 \%, \mathrm{w} / \mathrm{v})$ & 44.8 \\
Peptone $(0.5 \%, \mathrm{w} / \mathrm{v})+$ Beef extract $(0.5 \%, \mathrm{w} / \mathrm{v})$ & 36.4 \\
Malt extract $(0.5 \%, \mathrm{w} / \mathrm{v})+$ Beef extract $(0.5 \%, \mathrm{w} / \mathrm{v})$ & 36.8 \\
Beef extract $(0.5 \%, \mathrm{w} / \mathrm{v})+$ Yeast extract $(0.5 \%, \mathrm{w} / \mathrm{v})$ & 24.0 \\
Yeast extract $(0.5 \%, \mathrm{w} / \mathrm{v})+$ Malt extract $(0.5 \%, \mathrm{w} / \mathrm{v})$ & 33.8 \\
\hline
\end{tabular}

It has also been reported by Ghosh et al. (1996) that organic nitrogen such as peptone and yeast extract are preferred for lipase production by various pseudomonads (viz. Pseudomonas sp., $P$. fragi, $P$. fluorescens $\mathrm{BW}$ 96CC). Various concentrations $(0.25-5.5 \%, \mathrm{w} / \mathrm{v})$ of peptone were supplemented in the medium to investigate their effect on lipase production. Results showed that there was an increase in lipase production with increase in the concentration of peptone up to $3 \%$ $(\mathrm{w} / \mathrm{v})$ and thereafter, a decline was recorded. The enzyme activity at this concentration of peptone was $112 \mathrm{IU} / \mathrm{mL}$ (Fig. 5).
The higher concentration of peptone was inhibitory for lipase synthesis. This could be due to complex nature of this nitrogen source and some constituents might have toxic effect on lipase production at higher concentrations. Complex nitrogen sources, such as yeast extract, peptone, soybean meal and corn steep liquor, have traditionally been used for lipase production (Sharma et al. 2001). An increase in lipase production from Pseudomonas sp. KWI-56 was also observed in a medium containing peptone at a concentration of 3\% (w/v) (Izumi et al. 1990).

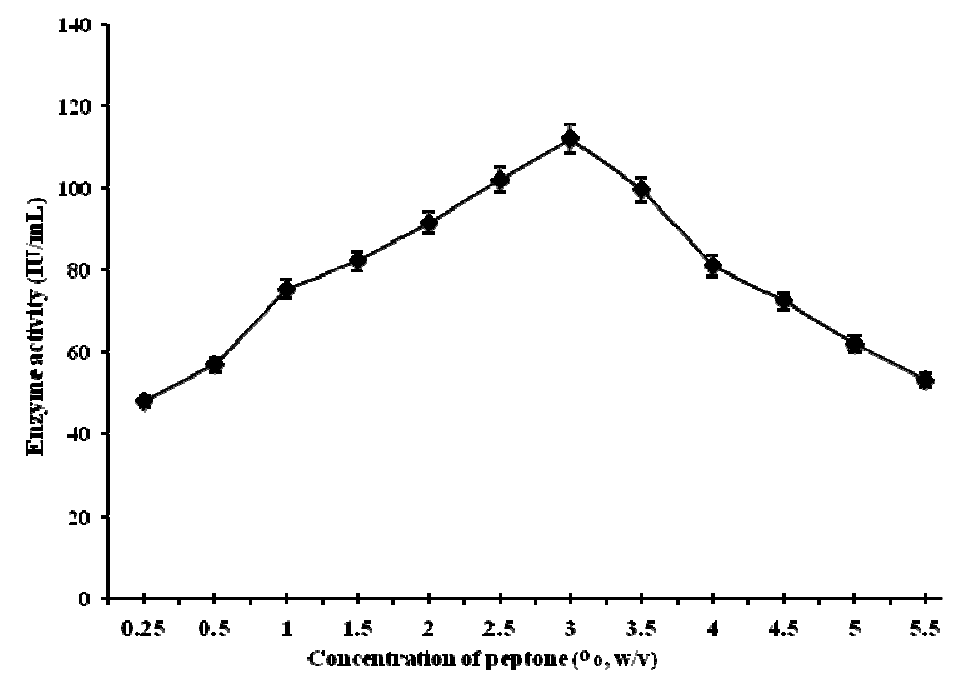

Figure 5 - Lipase production by Pseudomonas sp. BWS-5 with concentration of peptone as a function.

\section{Effect of different trace elements}

The presence of trace elements in the production medium plays a vital role in the enzyme production. The effect of various trace elements at different concentrations $(0.01,0.05$ and $0.1 \%$, w/v $)$ was examined individually on lipase production.
The supplementation of the culture medium with solution of different salts substantially improved the enzyme production individually, thereby indicating the requirement of the trace elements for lipase production by Pseudomonas sp. BWS-5. The results presented in Figure 6 clearly revealed 
that some salts such as potassium chloride $(0.05 \%$, $\mathrm{w} / \mathrm{v})$, manganese chloride $(0.05 \%, \mathrm{w} / \mathrm{v})$, ammonium molybdate $(0.05 \%$, w/v) and calcium chloride $(0.1 \%, w / v)$ enhanced the lipase production individually at respective concentrations. The maximum lipase production $(215.2 \mathrm{IU} / \mathrm{mL})$ was achieved with the supplementation of the medium with potassium chloride $(0.05 \%, \mathrm{w} / \mathrm{v})$. Further, the selected trace elements, which were responsible for enhanced lipase production, were tested together in different combinations but no considerable synergetic effect of these combinations was observed on enhancement of lipase production as shown by $\mathrm{KCl}$ alone, hence, only $\mathrm{KCl}$ was selected for further investigations. The stimulatory effect of trace element such as $\mathrm{KCl}$ on lipase production from Pseudomonas gessardii has been earlier reported by Ramani et al. (2010).

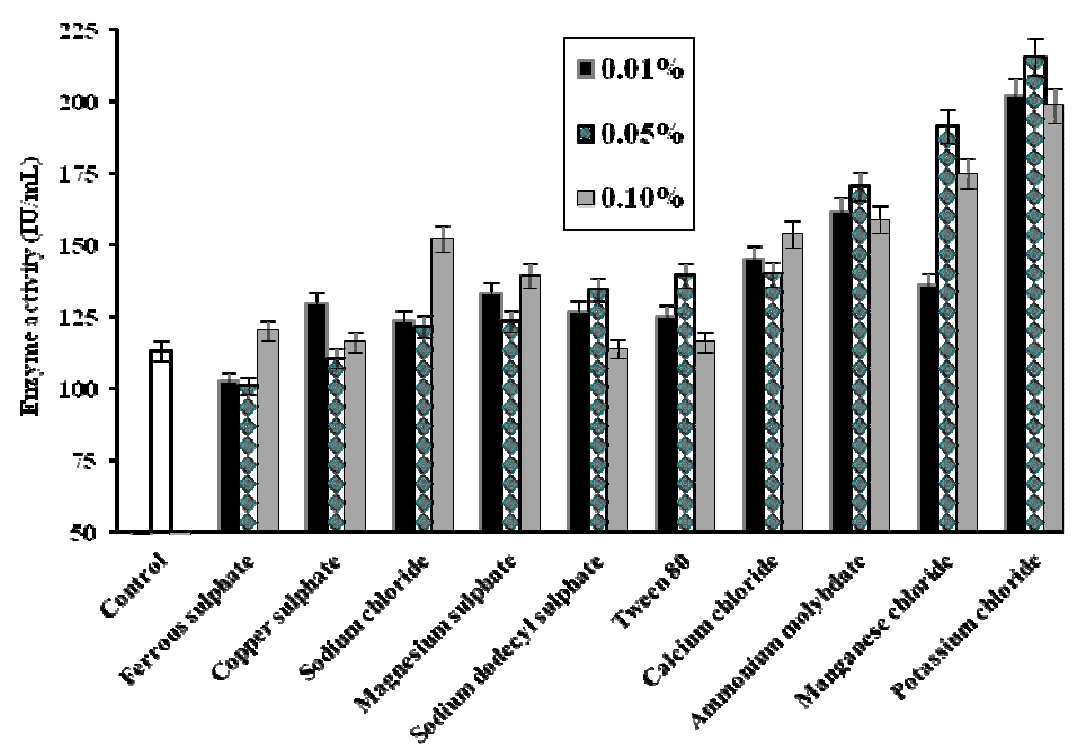

Figure 6 - Effect of various trace salts on lipase production.

\section{Process Optimization Studies at Shake Flask Level \\ Effect of $\mathrm{pH}$ and temperature}

Figures 7 and 8 showed the effect of $\mathrm{pH}$ of the medium and temperature of incubation on lipase production, respectively. There was an increase in enzyme production with the increase of initial $\mathrm{pH}$ of medium up to $6.5(223.5 \mathrm{IU} / \mathrm{mL})$ and thereafter, it declined (Fig. 7). Change in the external $\mathrm{pH}$ might alter the ionization of nutrient molecules and thus reduce their availability to the organism. In addition, drastic variations in $\mathrm{pH}$ can also harm the microbial cells by disrupting the plasma membrane and disturbing their metabolism. Further, the increase in lipase activity was observed with the increase of temperature up to $37^{\circ} \mathrm{C}$ and it was almost constant till $40^{\circ} \mathrm{C}$, and thereafter it decreased (Fig. 8). The rate of enzymatic reactions in the cells increases with the increase in temperature till optimum temperature and enzyme inactivation due to protein denaturation beyond this optimum temperature causing the slow metabolism of cells, which ultimately affects the cell growth and productivity. The gelling of plasma membrane at low temperatures also results in slowing down of transport processes in the microbial cells (Sahu and Martin 2011). Hence, the maximum activity of the lipase from Pseudomonas sp. BWS-5 was obtained at $\mathrm{pH} 6.5$ and temperature $37^{\circ} \mathrm{C}$ in the present investigations. Noman et al. (2010) also obtained the maximum lipase activity from $P$. aeruginosa $\mathrm{BN}-1$ at $37^{\circ} \mathrm{C}$ by using medium of $\mathrm{pH}$ at 6.5 . The maximum enzyme production at $37^{\circ} \mathrm{C}$ from Pseudomonas sp. has also been reported by Gilbert et al. (1991) and Rashid et al. (2001) in their studies. The highest lipase production (147.36 IU/mL) from $P$. aeruginosa SRT9 was also achieved at $37^{\circ} \mathrm{C}$ by Prita (2011). Generally, bacterial species prefer $\mathrm{pH}$ around 7.0 for best 
growth and lipase production; however, medium $\mathrm{pH}$ more than 7.0 has also been reported by some workers for maximum lipase production from
Pseudomonas sp. (Gilbert et al. 1991; Dong et al. 1999; Kanwar et al. 2002).

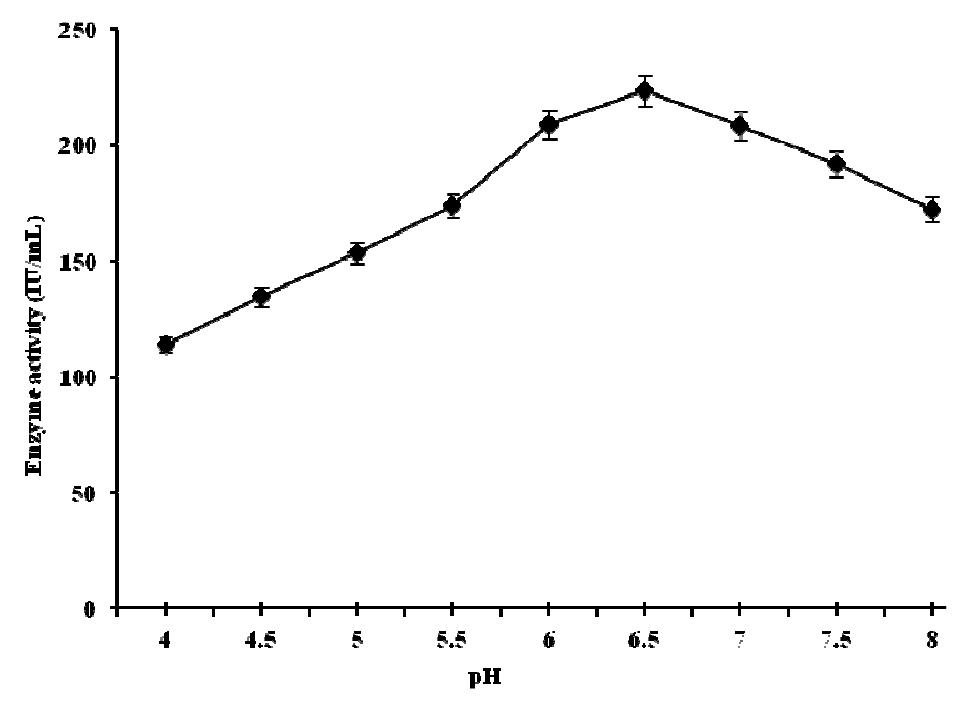

Figure 7 - Effect of $\mathrm{pH}$ on lipase production.

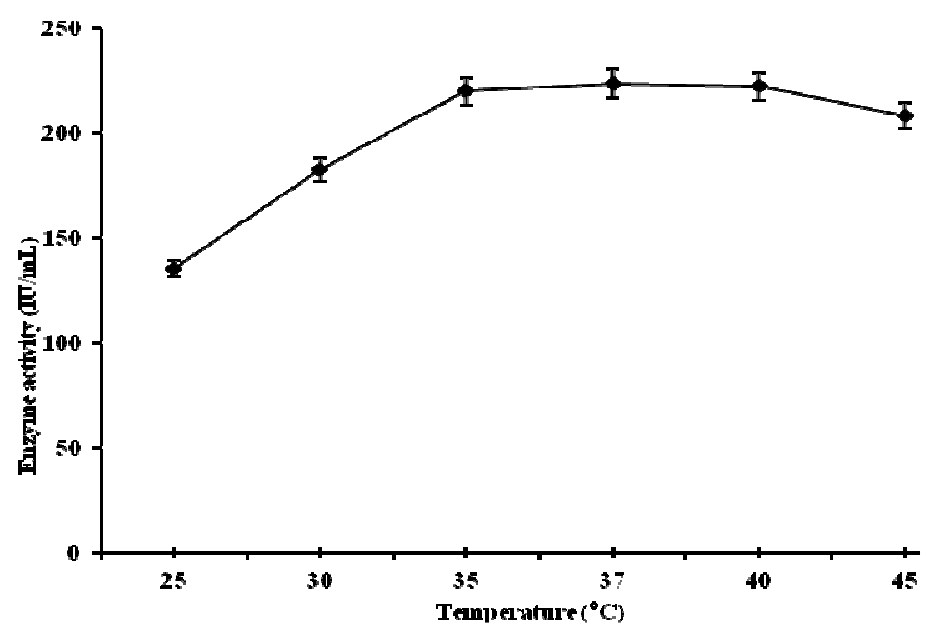

Figure 8 - Effect of temperature on lipase production.

\section{Effect of agitation}

Results shown in Figure 9 revealed that agitation exerted a strong influence on lipase production from Pseudomonas sp. BWS-5 and there was a significant increase in enzyme activity under agitation mode as compared to stationary condition. A progressive increase in enzyme production $(252.5 \mathrm{IU} / \mathrm{mL})$ was observed with the increase in agitation rate up to $150 \mathrm{rpm}$ and thereafter, a decrease in enzyme activity was recorded. Pabai et al. (1996) also observed that $150 \mathrm{rpm}$ agitation rate as the best for lipase production by Pseudomonas fragi, P. putida and $P$. fluorescens. Agitation rate not only affects oxygen availability but it also exerts influence on the availability of other nutrients in the medium. Low enzyme activity at higher agitation rates may be attributed to the effect of shear stress on bacterial cells as well as on the enzyme structure (Calderbank and Moo-Young 1959). 


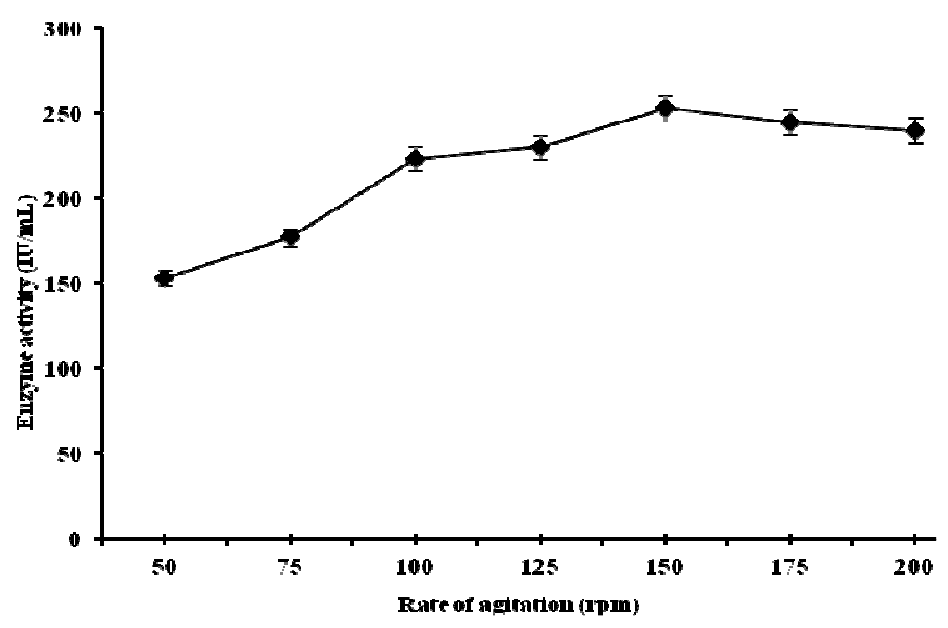

Figure 9 - Effect of agitation on lipase production.

\section{Effect of incubation time}

The results in Figure 10 showed that there was an increase in enzyme production up to $36 \mathrm{~h}$ of incubation and thereafter, it decreased. A decline in enzyme activity after $48 \mathrm{~h}$ of fermentation could be either due to decrease in nutrient availability in the medium or catabolite repression of enzyme. However, some workers have attained maximum lipase production after $72 \mathrm{~h}$ and $96 \mathrm{~h}$ incubation from $P$. fragi and $P$. fluorescens, respectively (Pabai et al. 1996; Dong et al. 1999).

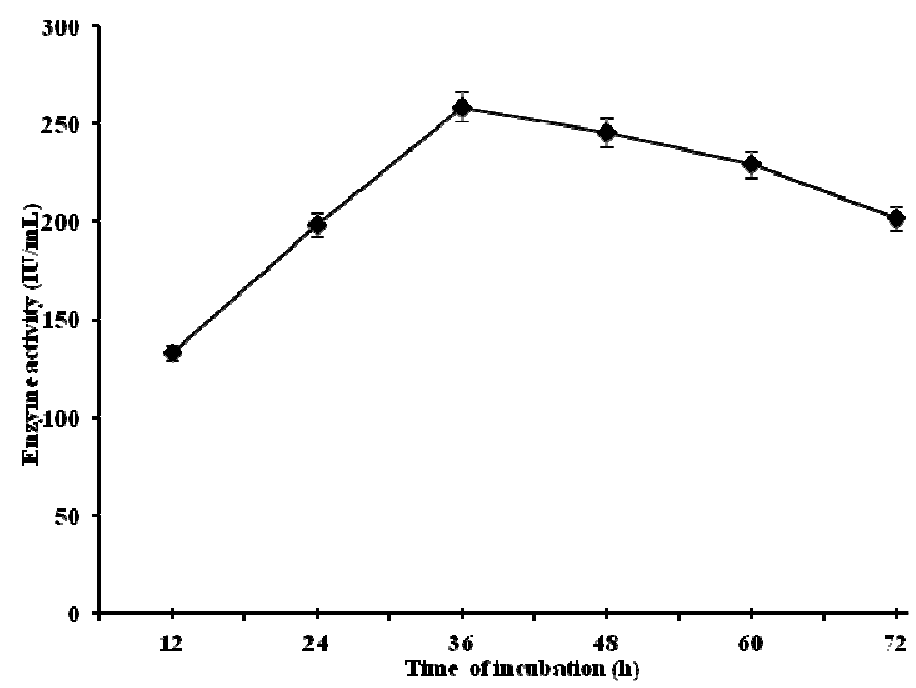

Figure 10 - Effect of incubation time on lipase production.

\section{Bioreactor Studies}

A significant increase in lipase production (277 $\mathrm{IU} / \mathrm{mL}$ ) was observed in a bioreactor as compared to enzyme production at shake flask level, when all the parameters optimized at flask level were used in the bioreactor studies. This could be due to continuous supply of oxygen to bacterial culture and also uniform distribution of medium components by the agitation. Results presented in Figure 11 showed that there was an increase in enzyme production $(290 \mathrm{IU} / \mathrm{mL})$ on increasing the agitation rate up to $200 \mathrm{rpm}$ and thereafter, a decrease in enzyme production was observed. Low enzyme activity at higher agitation rate could be attributed to the effect of shear stress on bacterial cells and on enzyme structure. An increase in 
enzyme production (298 IU/mL) was also recorded with the increase in aeration rate up to $0.75 \mathrm{vvm}$ and thereafter, a decline at higher aeration rate was observed (Fig. 12). The higher enzyme production could be due to the enhancement in oxygen transfer. The effect of incubation time on enzyme production was also studied at $6 \mathrm{~h}$ intervals up to $54 \mathrm{~h}$ of fermentation. It was observed that enzyme production started after $6 \mathrm{~h}$ of incubation and maximum enzyme production $(298 \mathrm{IU} / \mathrm{mL})$ was observed at $30 \mathrm{~h}$ of incubation (Fig. 13). Thus, aeration and agitation were critical factors for the Pseudomonas sp. BWS-5 for lipase production. The rise in death rate of cells with increase of agitation rate has already been established and this increase in death rate may be due to the influence of shear stress by blade tips of the impeller. The sensitivity to shear stress being an intrinsic characteristic of microorganisms varies from strain to strain (SilvaSantisteban and Filho 2005). The reduction in optimum incubation time to $30 \mathrm{~h}$ for maximum lipase production could be attributed to continuous aeration/enhanced oxygen transfer, uniform suspension of microbial cells and homogeneous nutrient medium in bioreactor because these factors affected the physiology of bacterial cells by meeting their metabolic requirements.

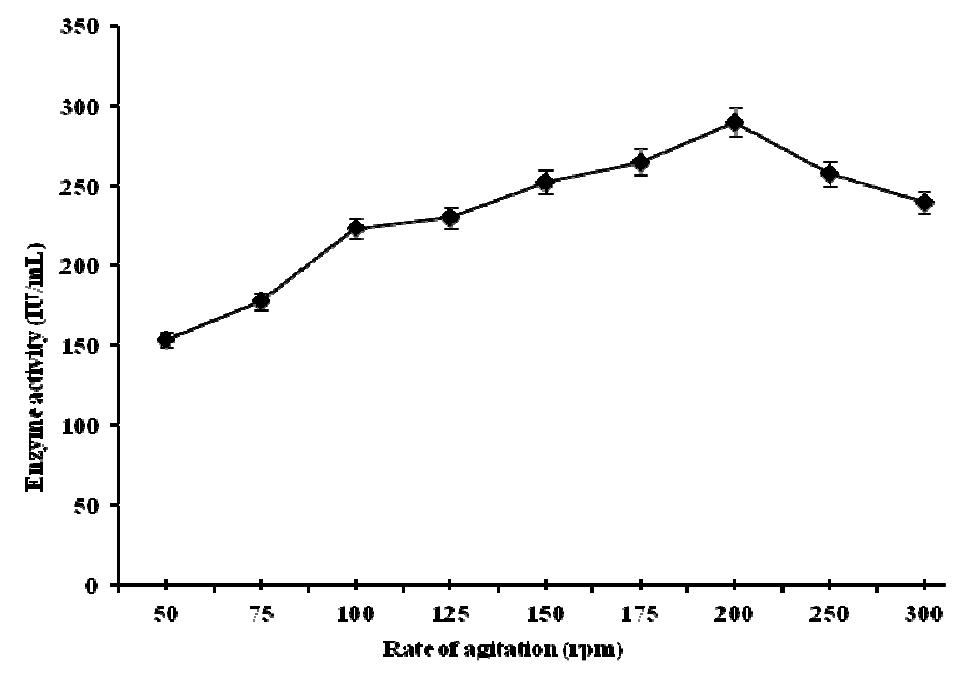

Figure 11 - Effect of agitation on lipase production.

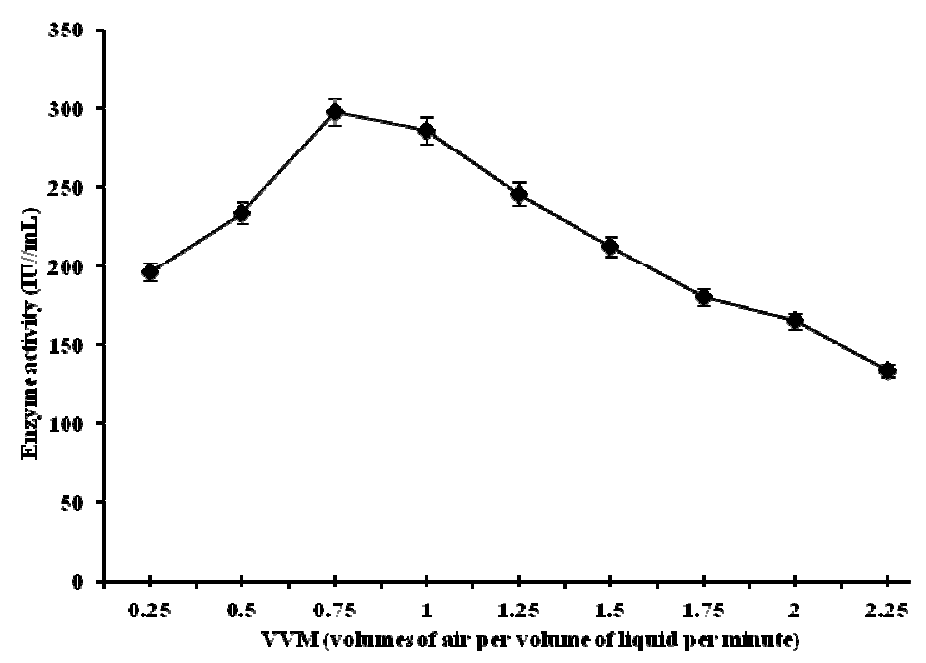

Figure 12 - Effect of air supply on lipase production. 


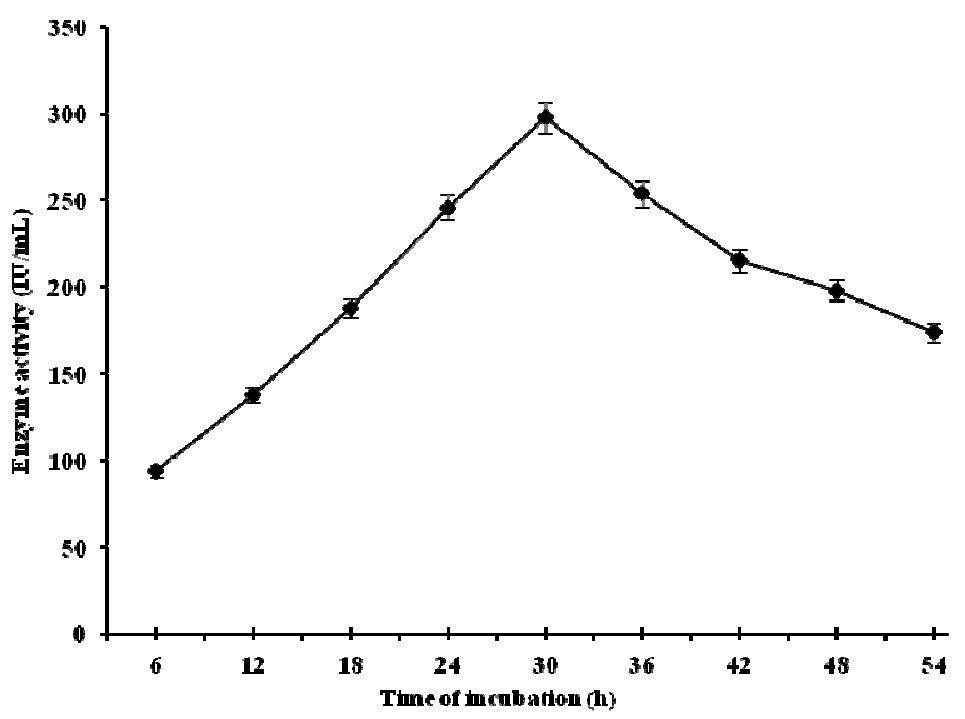

Figure 13 - Effect of incubation time on lipase production.

\section{CONCLUSIONS}

The maximum lipase production of $298 \mathrm{IU} / \mathrm{mL}$ from Pseudomonas sp. BWS-5 was obtained in its logarithmic phase of growth with simple medium containing glucose $(1 \%, \mathrm{w} / \mathrm{v})$, peptone $(3 \%, \mathrm{w} / \mathrm{v})$ and $\mathrm{KCl}(0.05 \%, \mathrm{w} / \mathrm{v})$ at $37^{\circ} \mathrm{C}$ after $30 \mathrm{~h}$ of incubation at lab scale bioreactor. The aeration and agitation were critical factors for the Pseudomonas sp. BWS-5 for lipase production. The simple medium, less fermentation time and low agitation rates are considered economical for higher scale enzyme production and hence, the good lipase production after $30 \mathrm{~h}$ of incubation with $0.75 \mathrm{vvm}$ of air supply at $200 \mathrm{rpm}$ as obtained optimal in this study would be an added advantage.

\section{ACKNOWLEDGEMENTS}

The authors are thankful to Department of Biotechnology, Punjabi University, Patiala, for providing necessary laboratory facilities.

\section{REFERENCES}

Beisson F, Tiss A, Riviere C, Verger R. Methods for lipase detection and assay: A critical review. Eur $J$ Lipid Sci Technol. 2000; 102: 133-153.
Calderbank PH, Moo-Young MB. The prediction of power consumption in the agitation of non-newtonian fluids. Trans Inst Chem Eng. 1959; 37: 26-33.

Choo DW, Kurihara T, Suzuki T, Soda K, Esak N. A cold adapted lipase on an Alaskan psychrotroph Pseudomonas sp. strain B11-1: Gene Cloning and Enzyme Purification and Characterization. Appl Environ Microbiol. 1998; 64: 486-491.

Dong H, Gao S, Han S, Cao S. Purification and characterization of a Pseudomonas sp. lipase and its properties in non-aqueous media. Appl Microbiol Biotechnol. 1999; 30: 251-256.

Elibol M, Ozer D. Influence of oxygen transfer on lipase production by Rhizopus arrhizus. Proc Biochem. 2000; 36: 325-329.

Ghosh PK, Saxena RK, Gupta R, Yadav RP. Microbial lipases: Production and applications. Sci Prog. 1996; 79: 119-157.

Gilbert EJ, Drozd JW, Jones CW. Physiological regulation and optimization of lipase activity in Pseudomonas aeruginosa EF2. J Gen Microbiol. 1991; 137: 2215-2221.

Gupta R, Gupta N, Rathi P. Bacterial lipases: An overview of production, purification and biochemical properties. Appl Microbiol Biotechnol. 2004; 64: 763781.

Iwai M, Tsujisaka Y. Fungal lipases. In: Borgstrom B, Brockman, editors. Lipases. Amsterdam: Elsevier; 1984. p. 443-449.

Izumi T, Nakamura K, Fukase T. Purification and characterization of a thermostable lipase from newly isolated Pseudomonas sp. KWI-56. Agric Biol Chem. 1990; 54: 1253-1258. 
Jensen RG. Detection and determination of lipase activity from various sources. Lipids. 1993; 18: 650657.

Kanwar L, Gogoi BK, Goswami P. Production of a Pseudomonas lipase in n-alkane substrate and its isolation using an improved ammonium sulfate precipitation technique. Bioresour Technol. 2002; 84: 207-211.

Kashmiri MA, Adnan A, Butt BW. Production, purification and partial characterization of lipase from Trichoderma viride. Afr J Biotech. 2006; 5(10): 878882.

Kiran GS, Shanmughapriya S. Optimization of extracellular psychrophilic alkaline lipase produced by marine Pseudomonas sp. (MSI057). Bioproc Biosys Eng. 2008; 31: 83-92.

Noman S, Samina I, Saeeda B. Purification and characterization of $60 \mathrm{kD}$ lipase linked with chaperonin from Pseudomonas aeruginosa BN-1. J Afr Biotechnol. 2010; 9(45): 7724-7732.

Pabai F, Kermasha S, Morin A. Use of continous culture to screen for lipase producing microorganisms and interesterification of butterfat by lipase isolates. Can J Microbiol. 1996; 42: 446-452.

Pandey A, Benjamin S, Soccol CR, Nigam P, Krieger A, Soccol VT. The realm of microbial lipases in biotechnology. Biotech Appl Biochem. 1999; 29: 119131.

Patel R, Mital D, Singh SP. Extracellular alkaline protease from a newly isolated haloalkaliphilic Bacillus sp.: Production and optimization. Proc Biochem. 2005; 40: 569-575.

Prita B. Immobilization and stabilization of Pseudomonas aeruginosa SRT9 lipase on tri (4formyl phenoxy) cyanurate. Kor J Chem Eng. 2011; 28(3): 867-874.
Ramani K, Chockalingam E, Sekaran G. Production of a novel extracellular acidic lipase from Pseudomonas gessardii using slaughterhouse waste as a substrate. $J$ Ind Microbiol Biotechnol. 2010; 37: 531-535.

Rashid N, Shimada Y, Ezaki S, Atomi H, Imanaka T. Low temperature lipase from psychrotrophic Pseudomonas sp. Strain KB700A. Appl Environ Microbiol. 2001; 67: 4064-4069.

Reed G. Microbial Lipases In: Reed G, editor. Enzymes in Food Processing. 2nd ed. New York: Academic Press; 1975.p.13-16.

Saad RR. Production of lipase from Aspergillus tamarii and its compatibility with commercial detergents. Folia Microbiol. 1995; 40: 263-266.

Sahu GK, Martin M. Optimization of growth conditions for the production of extracellular lipase by bacterial strains from dairy industry effluents Biotechnol Bioinf Bioeng. 2011; 1(3): 305-311.

Sharma R, Christi Y, Banerjee UC. Production, purification, characterization and application of lipases. Biotech Adv. 2001; 19: 627-662.

Silva-Santisteban YBO, Filho FM. Agitation, aeration and shear stress as key factors in inulinase production by Kluyveromyces marxianus. Enz Microb Technol. 2005; 36: 717-724.

Singh SK, Felse AP, Nunez A, Foglia TA, Gross RA. Regioselective enzyme-catalyzed synthesis of phospholipid esters, amides and multifunctional monomers. J Organic Chem. 2003; 68: 5466-5477.

Thirunavukarasu T, Edwinoliver NG, Abarasan SD. Removal of a triglyceride soil from fabrics by a novel lipase from Cryptococcus sp. S-2. Proc Biochem. 2008; 43: 701-706. 